\title{
СЕМАНТИКО-ПРАГМАТИЧНИЙ ПОТЕНЦІАЛ АКСІОЛОГІЧНОЇ ПОТУЖНОСТІ АНГЛІЙСЬКОГО ПРИКМЕТНИКА: ПСИХОЛОГІЯ ЙОГО СПРИЙНЯТТЯ В ПРОЦЕСІ ВИВЧЕННЯ АНГЛІЙСЬКОЇ МОВИ ЯК IHO3EMHÖ̈
}

У дослідженні з'ясовано семантико-прагматичний потенціал аксіологічної потужності англійського прикметника: психологія його сприйняття в процесі вивчення англійської мови як іноземної. Прикметник має своєрідну вербалізацію, прагматичну цінність і бере участь у формуванні та розвитку мовної свідомості, що проєктується на можливості концептуалізації аксіологічності, репрезентує сукупність оцінних, якісних, культурних та світоглядних характеристик, які відображаються в особливій взаємодії різних засобів мовної виразності.

Ключові слова: прикметник, аксіологія, категорія оцінки, англійська мова, вивчення мови, семантика.

Kovtun O. Semantic and Pragmatic Potential of the Axiological Power of an English Adjective: the Psychology of Its Perception in the Process of Learning English as a Foreign Language. The study clarifies the semantic and pragmatic potential of the axiological power of an English adjective: the psychology of its perception in the process of learning English as a foreign language. The novelty of the study lies in the fact that in the Western linguistic tradition the role of adjectives in the expression of evaluative meanings has not been fully studied. The purpose of this study is to demonstrate the axiological load and the special semantic and pragmatic nature of an English adjective to develop an understanding of the feasibility of using adjective forms in communication of university students. A comprehensive methodology, based on a wide range of techniques such as comparison, interpretation, abstraction, classification, functional-communicative and discourse analysis, was used to describe the evaluative power of English adjective forms to improve the effectiveness of learning English. Having studied the English adjectives, we concluded that they form a kind of qualitative layer of reality, which is considered to be the "fourth spatial dimension of the world", giving the trends of globalization. An adjective has a kind of verbalization, pragmatic value and participates in the formation and development of linguistic consciousness, which is projected on the possibility of conceptualization of axiology, represents a set of evaluative, qualitative, cultural and ideological characteristics, which are reflected in the special interaction of various means of speech. We consider that it is important and promising to conduct a comparative study of the axiological power of adjectives, which can be carried out on the basis of Slavic and 
non-Slavic languages, which will deepen the study of the problem, will help to gain understanding of the inner essence of language and its linguistic culture.

Keywords: adjective, axiology, category of evaluation, English language, language learning, semantics.

\section{Вступ}

Напрями лінгвістики й навчання мов завжди взаємопов'язані та взаємозалежні. Викладання англійської мови - це не лише навчальний процес, але й процес формування особистості, системи цінностей людини. «Упровадження аксіологічного підходу до розвитку міжкультурних компетентностей студентів університетів можна успішно здійснити, якщо сформувати їхн ціннісне ставлення до вивчення іноземної мови» (Valeev, \& Kondrat'eva, 2015), що безпосередньо залежить від психологічних особливостей сприйняття іноземної мови загалом та їі конкретних фрагментів зокрема.

Найбільш виразно маркованим класом слів в аспекті лінгвоаксіології традиційно вважають прикметник. Уживання прикметників у мовленні робить його більш точним і колоритним, ознаково насиченим. Прикметники допомагають номінувати риси суб’єкта або об'єкта, схарактеризувати їх з різних ракурсів, дати образний і яскравий опис, виразити оцінку. Прикметник спроєктований на вербалізацію розмаїття ознак, загальна кількість яких дає змогу людині всебічно пізнати суть об'єктивної реальності, удосконалити мовний образ світу, змоделювати широку систему конотацій (див. про це Hunston, 2019). Прикметники сприяють реконструкції світогляду мовної свідомості, допомагають увиразнити реальність, упорядкувати реалії довкілля відповідними мовними засобами.

Мета цієї наукової розвідки - продемонструвати аксіологічну навантаженість та особливу семантичну й прагматичну природу прикметника англійської мови для вироблення в здобувачів вищої освіти розуміння доцільності використання прикметникових форм у комунікативній діяльності.

Для досягнення поставленої мети актуалізуємо такі завдання: 1) з'ясувати ступінь поширеності англійської мови та їі культурних цінностей; 2) визначити аксіологічну потужність англійських прикметників; 3) репрезентувати основні лексико-семантичні групи прикметників англійської мови; 4) проаналізувати роль прикметника 
як складника світогляду лінгвоособистості; 5) розкрити психологію сприйняття прикметника в процесі вивчення англійської мови як іноземної.

Сьогодні англійська мова, без сумніву, відіграє надзвичайно важливу роль у житті людей насамперед як засіб міжнародного спілкування. Вона, як відомо, прийнята офіційною робочою мовою ООН. Англійську мову використовують під час самітів та зустрічей глав урядів, прийняття законів та указів; відповідні переговори, дебати та дискусії проводять також англійською мовою. Ї̈̈ застосовують у сфері міжнародної торгівлі, банківських операціях, морських, наземних і повітряних перевезеннях. Англійська мова сприяє реальному науковому спілкуванню вчених світу. Міжнародні конференції, вивчення передового досвіду та обмін науковою інформацією подається переважно англійською. Отже, англійська мова є невід'ємним складником набору цінностей сучасної людини. Аксіологічний світогляд особистості будується не лише за допомогою рідної мови, але й англійської. Тому роль «процесу викладання англійської мови як розвитку гуманістичних цінностей шляхом реалізації мовних цінностей засобами аксіологічної лінгвістики є дуже важливою» (Zerkina, Lomakina, \& Kostina, 2015).

Аксіологічний аспект життя став значущим на сучасному етапі соціального розвитку й у реальному, й у віртуальному середовищі. Оцінка - феномен, що встановлює аксіологічне ставлення суб'єкта до об'єкта та репрезентує результат цього ставлення. Вона $є$ невід'ємною частиною процесу, що відображає сучасну реальність і має когнітивний характер (Zerkina, Lomakina, \& Kostina, 2015). Сприймаючи довкілля, особистість не може уникнути оцінки явищ і фактів дійсності, висловлення особистого ставлення до них.

Мова - засіб передачі інформативних даних, вона розвиває людський інтелект, створює нові тексти, які також мають забезпечувати циркуляцію інформації, зокрема й концептуальну, ціннісну (Zerkina, Lomakina, \& Kostina, 2015). Саме тому ретельне вивчення особливостей словникового запасу, що передає різні способи й види оцінки, надзвичайно важливе в процесі вивчення мовної структури та ії особливих характеристик, психології сприйняття мовлення.

У статті «Dimensions of evaluation» («Виміри оцінки») Моніки Беднарек схарактеризовано специфіку омовлення емоційного 
й раціонального типів оцінки. Названа авторка наголошує, що оцінка лежить в основі категоризації понять, що виявляються в мовленні. Вона описує прямий зв'язок між цінностями та мовою й показує, що вираження значення оцінки тісно пов'язане з емоціями. Процес оцінювання, зрозуміло, має антропоцентричний характер, оскільки, оцінюючи суб’єкт чи об'єкт, людина має пропустити його ознаки крізь свою свідомість (Bednarek, 2009а). Однак очевидно, що емоції $€$ відображенням конкретної системи цінностей, яка є закономірною властивістю певного дискурсу або може очікуватися, бути потенційною в межах відповідної дискурсивної практики. Тоді ця сукупність цінностей, як пояснює Моніка Беднарек, «стратегічно пов’язана із самопрезентацією [...] або є конвенціоналізованим, буденним дискурсом» (Bednarek, 2009b: 405). Отже, “мова оцінки” (мовлення, у якому виражаються оцінні смисли) $є$ не лише дзеркалом індивідуального мислення (“особистого розуму”), але й відповідного “соціального розуму” чи культури.

Глобалізація, безперечно, складний процес, у якому системи цінностей і пріоритети суперечать один одному. Оптимальний сценарій може бути пов'язаний з визнанням багатьох аксіологічних, політичних та етнічних світоглядів, їх “мирним співіснуванням”, сформованим у процесі викладання англійської мови (Zerkina, Lomakina, \& Kostina, 2015). Єдиним варіантом такого співіснування різних світоглядів, що глобалізується, уважають толерантність, повагу до чужого, усіх мов, особистісної свободи та цінностей інших народів. Повага до їхної духовності, лінгвокультур слугує підгрунтям спільних аксіологічних орієнтирів. Мови міжнародного спілкування, серед яких вирізняється англійська, стають не лише засобом спілкування, а й путівником загальнолюдських цінностей, засобом розвитку толерантного ставлення до цінностей іноземного світу (Zerkina, Lomakina, \& Kostina, 2015).

На сучасному етапі розвитку лінгвістичної науки, коли передусім постала проблема взаємозв'язку та взаємодії семантики й прагматики, вивчення оцінних особливостей є особливо актуальним. Цей напрям досліджень входить до антропоцентричної парадигми сучасної лінгвістики.

Оцінку інтерпретують як чинник, що формує картину глобальних цінностей, оскільки ціннісні уявлення властиві кожній культурі. 
Оцінка базується на уявленнях, людських знаннях, а також на системі національних і культурних стереотипів, психології їх сприйняття. Лінгвофілософська категорія оцінки визнана основним способом відображення системи цінностей у мові. Під час вербалізації і граматикалізації категорії оцінки втілюються лінгвістичні світоглядні уявлення про те, що можна вважати реальним чи ірреальним, істинним чи неправдивим, позитивним чи негативним тощо.

Прикметник - особлива частина мови, що, зрозуміло, аспектуально дає змогу пізнати суть об'єктивної реальності, сформувати у свідомості багатобарвний образ світу та характеризувати його як мовний знак із широкою палітрою конотацій.

Своєрідність аксіологічної спроможності прикметників вивчали, зокрема, Дж. Р. Айзер (1976), Р. Струтон (1990), Е. Станкевич (1964), Л. Грей (1999), Ч. Стівенсон (1985), С. Ханстон (2019). Проблеми лінгвоаксіології на матеріалі англійської мови були у фокусі уваги таких учених: О. Єсперсена (1933), У. Лабова (1972), О. М. Вольф (1978), I. В. Арнольд (1986), Дж. Лакоффа (1987), Сьюзан Ханстон і Джоффа Томпсона (2000), Джеймса Мартіна (2002, 2004, 2010), Майкла Халідея і Крістіана Метьєсена (2004), Джеймса Мартіна й Пітера Уайта (2005), Роберта Енглберстона (2007), Моніки Беднарек (2006, 2008, 2009), Бруно Бари (2010), Елени Котос (2014), Пітера Уайта $(2015,2016)$, Є. Ф. Серебреннікова (2016), Рут Бріз та Інесс Олзи (2017), Сьюзан Ханстон $(2008,2011,2019)$ та інших.

Сфокусувавши увагу на найбільш авторитетних і цитованих дослідженнях ключових науковців, задіяних у сфері лінгвоаксіології, помічаємо, що в західній лінгвістичній традиції простежуємо наявність фрагментарних праць з лінгвоаксіології, усе ще мало дослідженою залишається роль прикметників у вираженні оцінних значень.

\section{Методи дослідження}

Для опису оцінної потужності прикметникових форм англійської мови, активізації ефективності вивчення англійської застосовано комплексну методику, що грунтується на широкому спектрі прийомів: порівняння, інтерпретація, абстрагування, класифікація, функційно-комунікативний і дискурсивний аналіз. Дослідження семантико-прагматичного потенціалу аксіологічної потужності англійського прикметника здійсннено на матеріалі тлумачного словника 
англійської мови «Oxford Advanced Learner's Dictionary of Current English» (Hornby, 1989) та словника символів «A Dictionary of Symbols» (Cirlot, 1973).

\section{Виклад основного матеріалу}

Прикметник посідає своєрідне місце в словниковому запасі кожної людини, частиномовній системі кожної мови, вирізняється тим, що найбільш послідовно й виразно вербалізує всі типи оцінки. Отже, прикметник належить до системи оцінної лексики з особливою історією становлення самостійного лексико-граматичного класу слів.

«Мову, зокрема прикметники, які використовують люди, можна застосовувати так, щоб зрозуміти різні аспекти ставлення до дійсності» (Matthew, \& Russell, 2014). Прикметники належать до ментальної (когнітивної, епістемічної) сфери, виражають широку палітру оцінок певних об'єктів чи ситуацій з огляду на багатоаспектне, багатовимірне ставлення до довкілля чи істини, соціальних та культурних моделей, ідеалів, норм, стандартів. Вони відіграють особливу роль у фіксації та оцінці знань, оскільки утворюють атрибутивний “nортрет” реального світу в мовній свідомості, що надалі допомагає створювати й оцінювати образи предметів, які оточують людину (Hunston, 2019).

Прикметники англійської мови, на думку С. Ханстон, можуть бути репрезентовані двома класами лексем: емпіричним та раціональним (Hunston, 2019). На сучасному етапі розвитку англійської мови визначено кілька груп емпіричних прикметників, тобто таких, що «номінують знаки, сприйняті органами чуття й усвідомлені внаслідок одноетапної операції розумового порівняння зі “стандартом"» (Bara, 2010; Bednarek, 2006). “Емпіричні” прикметники позначають власні ознаки конкретних предметів, їхній зміст повністю відповідає логічним і філософським категоріям. Однак прикметники зі значенням раціональної оцінки репрезентують ознаки, що не сприймаються органами чуття, а $є$ наслідком інтелектуальних процесів сприйняття, осмислення та порівняння. Зауважмо, що прикметникова належність до лексико-семантичної групи слів є досить відносною, якщо зважати на його абстрактне, узагальнене (категорійне) значення, оскільки в процесі функціювання цього класу слів простежуємо відповідні метаморфози, що репрезентують і трансформацію семантики, і розвиток конотацій, прагматичного значення. 
Отже, система прикметників дає змогу реконструювати світогляд особистості, продемонструвати “присутність” реальності у свідомості, насамперед мовній, відповідно “організувати” реалії об”єктивного світу. Дослідники вважають важливими для актуалізації аксіологічності комунікації такі лексико-семантичні групи прикметників (Hornby, 1989):

1. Прикметники, які виражають ознаки, що сприймаються органами чуття: (а) зорові (green, small, round), (б) слухові (quiet, loud), (в) запахові (odourless, aromatic), (г) смакові (tasty, sour), (д) тактильні (cold, wet, rough) та ті, що (е) сприймаються кількома чуттями (fresh) актуалізована невербальна параметризація.

2. Прикметники, що номінують часові характеристики (long, young, late, eternal).

3. Прикметники, які вказують на просторові характеристики (wide, narrow, bare, vast, infinite, boundless).

4. Прикметники, що характеризують людські здібності (clever, stupid, attentive).

5. Прикметники, що виражають емоційні характеристики людини (glad, sad, happy, optimistic).

6. Прикметники, що називають етичні, морально-психологічні якості людини, вербалізуючи негативну чи позитивну оцінку (innocent, noble, criminal, worthy).

7. Прикметники, які виражають узагальнені (логічні) ознаки, що позначають абстрактні поняття (particular, general, certain).

8. Прикметники, що описують стан людини та об’єктів довкілля, що визначаються напругою м’язів, характеристиками вимірів ваги, а також ознаки, які виявляються внаслідок фізичних процесів здавлювання, стискання, натискання, розтягування (vigorous, strong, heavy).

Прикметники репрезентують різні рівні бачення та розуміння світу: загальнолюдський, культурний, історичний, етнічний, соціальний, тому семантику прикметників окреслюють як «відображення пізнавальних практик людини». Прикметник має широке прагматичне значення. Це важливий чинник для створення та модифікації оцінних значень, оскільки він репрезентує різні їх види (Bara, 2010; Bednarek, 2006).

Слід пам'ятати, що стандарт порівняння sрунтується на єдносmі асоціативного мислення особистостей - членів суспільства. Отже, 
процес вивчення іноземної мови генерує сприйняття якісної етнокультурної специфіки англійської мови, що відображає не лише “англійський” світогляд, а й “англійський” спосіб оцінювання довкілля.

Семантика прикметників значною мірою зумовлена уявленнями про взаємозв’язок логічних категорій і знакових предметів, мови та думки (Hunston, 2019). Наприклад, еталонами чорного кольору, словесним знаком якого є прикметник black (чорний), слугують такі лексичні репрезентанти, як ніч, сажа або вугілля; еталонами білого кольору, що вербалізується прикметником white (білий), слугують слова сніг, молоко, сіль.

Прикметники англійської мови утворюють не лише єдину концептуальну оцінну сферу, але й уніфіковану якісно-кількісну. Учені вказують на особливість прикметникової багатозначності, що виражається в активному розвитку значення на основі актуалізації широкої палітри психологічних асоціацій, що виникають у мовній свідомості комунікантів (Bara, 2010; Bednarek, 2006; Hunston, 2019). У семантиці іменників і дієслів, на відміну від прикметникової семантики, зауважмо, домінує логічна основа розвитку нових значень. Вивчаючи засоби репрезентації різних понять у мові, можна отримати інформацію про властивості людської думки в різні історичні епохи, оскільки концептуальний світогляд постійно змінюється. Лінгвістичний світогляд зберігає систему значень, що формуються в процесі пізнання світу й знаходять вираження в словах, фразеологізмах, висловлюваннях, текстах, дискурсах (Zerkina, Lomakina, \& Kostina, 2015).

Наприклад, прикметник purple (øiолетовий) має конотативне значення, властиве лише англійській лінгвокультурі, оскільки цей колір уважається “королівським” й асоціюється з величністю. Це значення зафіксоване в системі фразеологізмів, наприклад: to be born (cradled) in (the) purple (бути народженим y фiолетовому) означає 'мати благородне походження'; 'бути належним до вишуканого роду'.

Семантичний опис прикметників неможливий без урахування ментальних виявів, що стосуються конкретних характеристик чи оцінок довкілля. Вони дають можливість поєднувати та протиставляти різні об'єкти дійсності, а також розпізнавати їх. У мові це реалізовано, як відомо, у тому, що прикметники можуть утворювати синонімні та антонімні ряди. 
Дефініційний аналіз лексикону англійської мови й зафіксовані приклади не забезпечують усебічного аналізу змісту понять, виражених прикметниками. Наприклад, уприкметника white (білиц̆), що є одним з найпоширеніших в англійській мові, можна виявити приховану семантику, що важлива для засвоєння знань, побудови синонімних рядів й опису інших системних взаємозв'язків, можливих для вираження системності прикметника. Вербалізація значення наведеного вище прикметника актуалізується через лексему white та ії семантичні еквіваленти: ashen (попелястий), colourless (безбарвний), pale (блідй), pallid (без кровинки), pasty (блідий як смерть), wan (блідий) тощо. Вищенаведені лексеми вербалізують різні характеристики абстрактного поняття “білий”. Однак, якщо виникає потреба належно схарактеризувати особливості репрезентації зазначеного поняття в процесі моделювання відповідних значень, що мають потенціал реалізації в конкретній лінгвокультурі, необхідно описати специфіку оцінних значень кожної конкретної лексеми. Звернімо увагу, що конкретне значення може мати неоднакову реалізацію в різних лінгвокультуpax (Zerkina, 2011). Отже, повний опис семантики прикметника white можливий лише з урахуванням семіотичних і символічних значень білого кольору з урахуванням специфіки його психологічного впливу на людину.

Згідно з результатами психологічних досліджень, що базуються на біопсихічному досвіді людини, білий колір асоціюється зі світлом: він указує напрямок і виражає такі смисли, як 'початок', 'чистота' та 'невинність' (Cirlot, 1973). Усе сказане стосовно семантики й прагматики аналізованої лексеми на позначення кольору (white), зокрема вияву оцінного смислу, що формується на його базі у свідомості людини, виражається символічними значеннями чистоти, простоти, невинності, правди, надіi, святості, милосердя, це також символ миру, прощення. Церква розглядає білий колір як колір Бога. Це колір Різдва, Великодня та Вознесіння. У британській лінгвокультурі white - забарвлення привидів, а у фольклорі - символ єдинорога. Це колір величності й аристократизму (Cirlot, 1973). Окрім того, чистота будь-якого кольору відображає чистоту його символічного значення. Базові кольори “передають” основні емоції; складні, багатокомпонентні кольори відображають складніші, “заплутаніші” поняття (Cirlot, 1973). Отже, аналіз смислового навантаження прикметника 
white доводить, що кожне оцінне значення формується у свідомості людини внаслідок іiі чуттєвого досвіду, практичної діяльності та узагальнень іï розуму. Процес формування оцінних значень постійний, регулярний, систематичний, його швидкість та якісні зміни залежать від інтра- та екстралінгвістичних чинників. Він грунтується на особливостях психологічного сприйняття.

\section{Висновки}

Англійські прикметники утворюють своєрідний якісний шар реальності, який уважають “четвертим просторовим виміром світу", ураховуючи тенденції глобалізації. Прикметник має своєрідну вербалізацію, прагматичну цінність і бере участь у формуванні та розвитку мовної свідомості, що проєктується на можливості концептуалізації аксіологічності, репрезентує сукупність оцінних, якісних, культурних і світоглядних характеристик, що відображаються в особливій взаємодії різних засобів мовної виразності.

Прикметники мають важливе значення в процесі навчання іноземної мови, оскільки розкривають її лексико-семантичний потенціал, знайомлять з лінгвокультурою, розширюють мовленнєві здібності лінгвоособистості.

Вивчення абстрактної лексики викликає велике зацікавлення, оскільки фундаментальні концепти, що передаються прикметниками, $€$ тими цеглинками, які будують лінгвістичну модель світу й лежать в основі інтерпретації дійсності та суджень. Окрім того, лінгвістичний аналіз оцінної лексики, репрезентованої прикметником, вимагає розробки спеціальних методів і прийомів, що сприяють розвитку нових напрямів мовознавства.

Нагальною залишається проблема доповнення вже наявної теорії, присвяченої граматичним механізмам породження оцінки й дослідженню всього граматичного потенціалу мови крізь призму граматики оцінки на базі англійської мови. Важливим і перспективним уважаємо контрастивне дослідження аксіологічної потужності прикметників, яке може бути здійснене на матеріалі слов'янських і неслов'янських мов, що слугуватиме глибшому вивченню проблеми, розумінню внутрішньої суті мови, iї лінгвокультури, сприятиме глибшому вивченню англійської мови як іноземної. 


\section{ЛІТЕРАТУРА}

1. Арнольд, И. В. (2012). Лексикология современного английского языка. Москва: ФЛИНТА: Наука. 2. Вольф, Е. М. (1978). Грамматика и семантика прилагательного: на материале иберо-романских языков. Москва: Наука. 3. Стивенсон, Ч. (1985). Некоторые прагматические аспекты значения. Новое в зарубежной тингвистике, 16, 129-155. 4. Bara, B. (2010). Cognitive Pragmatics: The Mental Processes of Communication. USA: MIT Press. 5. Bednarek, M. (2009a). Dimensions of evaluation. Cognitive and linguistic perspectives. Pragmatics and Cognition, 17 (1), 146-175. 6. Bednarek, M. (2009b). Emotion talk and emotional talk: Cognitive and discursive perspectives. In Language and Social Cognition. Expression of the Social Mind (pp. 395-431). Berlin: Mouton de Gruyter. 7. Bednarek, M. (2006). Evaluation and cognition: Inscribing, evoking and provoking opinion. In Language and Memory. Aspects of Knowledge Representation (pp. 187-221). Berlin: Mouton de Gruyter. 8. Cirlot, J. E. (1973). A Dictionary of Symbols. London: Routledge. 9. Eiser, J. R. (1975). Attitudes and the use of evaluative language: a two-way process. Journal for the Theory of Social Behaviour, 5, 235-248. 10. Gray, S. L. (1999). Mastering idiomatic English: Adjective Phrases. Moscow: National Textbook Company. 11. Hornby, A. S. (1989). Oxford Advanced Learner's Dictionary of Current English. Oxford: University Press. 12. Hunston, S. (2019). Language patterns and ATTITUDE revisited: adjective patterns, attitude and appraisal. Functions of Language, 26 (3), 343-371. 13. Jespersen, O. (1933). Essentials of English Grammar. London: George Allen and Unwin. 14. Matthew, D., \& Russell, H. (2014). The Evaluative Lexicon: Adjective use as a means of assessing and distinguishing attitude valence, extremity, and emotionality. Journal of Experimental Social Psychology, 56, 214-227. 15. Stankiewicz, E. (1964). Problems of Emotive Language. London: Routledge. 16. Struton, R. (1990). Philosopher on Dover Beach. Manchester: Carcanet Press. 17. Valeev, A. A., \& Kondrat'eva, I. G. (2015). Axiological Approach to the Development of Students' Intercultural Competences by Foreign Language Means. Procedia - Social and Behavioral Sciences, 191, 361-365. 18. Zerkina, N., Lomakina, Ye., \& Kostina, N. (2015). Axiological Linguistics and Foreign Language Teaching. Procedia - Social and Behavioral Sciences, 199, 254-260. 19. Zerkina, N. (2011). Explicit and implicit representation of the concept WHITE in English. Cognitive Studies of Language, 8, 405-406.

\section{REFERENCES}

1. Arnol'd, I. V. (2012). Leksikologija sovremennogo anglijskogo jazyka [Lexicology of Modern English]. Moskva: FLINTA: Nauka [in Russian]. 2. Vol'f, E. M. (1978). Grammatika i semantika prilagatel'nogo: Na materiale ibero-romanskih jazykov [Grammar and semantics of the adjective: Based on the material of the Ibero-Romance languages]. Moskva: Nauka [in Russian]. 3. Stivenson, Ch. (1985). Nekotorye pragmaticheskie aspekty znachenija [Some pragmatic aspects of meaning]. Novoe v zarubezhnoj lingvistike - New in foreign linguistics, 16, 129-155 [in Russian]. 4. Bara, B. (2010). Cognitive Pragmatics: The Mental Processes of Communication. USA: MIT Press [in English]. 5. Bednarek, M. (2009a). Dimensions of evaluation. Cognitive and linguistic perspectives. Pragmatics and Cognition, 17 (1), 146-175 [in English]. 6. Bednarek, M. (2009b). Emotion talk and emotional talk: Cognitive and discursive perspectives. In Language and Social Cognition. Expression of the Social Mind (pp. 395-431). Berlin: Mouton de Gruyter [in English]. 7. Bednarek, M. (2006). Evaluation and cognition: Inscribing, evoking and provoking opinion. In Language and Memory. Aspects of Knowledge Representation (pp. 187-221). Berlin: Mouton de 
Gruyter [in English]. 8. Cirlot, J. E. (1973). A Dictionary of Symbols. London: Routledge [in English]. 9. Eiser, J. R. (1975). Attitudes and the use of evaluative language: a two-way process. Journal for the Theory of Social Behaviour, 5, 235-248 [in English]. 10. Gray, S. L. (1999). Mastering idiomatic English: Adjective Phrases. Moscow: National Textbook Company [in English]. 11. Hornby, A. S. (1989). Oxford Advanced Learner's Dictionary of Current English. Oxford: University Press [in English]. 12. Hunston, S. (2019). Language patterns and ATTITUDE revisited: adjective patterns, attitude and appraisal. Functions of Language, 26 (3), 343-371 [in English]. 13. Jespersen, O. (1933). Essentials of English Grammar. London: George Allen and Unwin [in English]. 14. Matthew, D., \& Russell, H. (2014). The Evaluative Lexicon: Adjective use as a means of assessing and distinguishing attitude valence, extremity, and emotionality. Journal of Experimental Social Psychology, 56, 214-227 [in English]. 15. Stankiewicz, E. (1964). Problems of Emotive Language. London: Routledge [in English]. 16. Struton, R. (1990). Philosopher on Dover Beach. Manchester: Carcanet Press [in English]. 17. Valeev, A. A., \& Kondrat'eva, I. G. (2015). Axiological Approach to the Development of Students' Intercultural Competences by Foreign Language Means. Procedia - Social and Behavioral Sciences, 191, 361-365 [in English]. 18. Zerkina, N., Lomakina, Ye., \& Kostina, N. (2015). Axiological Linguistics and Foreign Language Teaching. Procedia - Social and Behavioral Sciences, 199, 254-260 [in English]. 19. Zerkina, N. (2011). Explicit and implicit representation of the concept WHITE in English. Cognitive Studies of Language, 8, 405-406 [in English].

Ковтун Оксана Володимирівна - кандидат філологічних наук, доцент кафедри теорії і практики перекладу факультету іноземних мов, Донецький національний університет імені Василя Стуса; вул. Академіка Янгеля, 4, Вінниця, 21007, Україна.

Tel.: +380979611640

E-mail: o.kovtun@donnu.edu.ua

https://orcid.org/0000-0002-9139-8987

Kovtun Oksana Volodymyrivna - Candidate of Philological Sciences (Ph.D.), Associate Professor at the Department of the Theory and Practice of Translation, Faculty of Foreign Languages, Vasyl Stus Donetsk National University; 4 Akademika Yanhelia Str., Vinnytsia, 21007, Ukraine.

Надійшла до редакції 14 березня 2021 року

\section{CITATION}

ДСТУ 8302:2015: Ковтун О. В. Семантико-прагматичний потенціал аксіологічної потужності англійського прикметника: психологія його сприйняття в процесі вивчення англійської мови як іноземної. Лінгвістичні дослідження: зб. наук. пр. Харк. нац. пед. ун-ту імені Г. С. Сковороди. Харків, 2021. Вип. 54. Ч. II. С. 141-152. DOI: https://doi.org/10.34142/23127546.2021.54.2.13

AРA: Ковтун, О. В. (2021). Семантико-прагматичний потенціал аксіологічної потужності англійського прикметника: психологія його сприйняття в процесі вивчення англійської мови як іноземної. Лінгвістичні дослідження, 54 (II), 141-152. DOI: https://doi.org/10.34142/23127546.2021.54.2.13 